\title{
Adama Podgóreckiego hipoteza trójstopniowego działania prawa a wybrane elementy koncepcji Ericha Fromma
}

\begin{abstract}
Jest rzeczą dość paradoksalną, że prawo - zjawisko tak bardzo związane z życiem - studiowane jest, jeśli idzie o zagadnienie jego działania, w sposób jakby umyślnie od spraw życiowych oddalony.
\end{abstract}

Adam Podgórecki ${ }^{1}$

Problematyka integracji prawoznawstwa jest dobrą okazją, by powrócić do bardzo interesującej i chyba trochę niedocenianej hipotezy trójstopniowego działania prawa, sformułowanej przez Adama Podgóreckiego. Powrót ten, zgodnie z zasada, wedle której przechowywanie tradycji nie powinno polegać na jej biernym odtwarzaniu, lecz na ciągłym ożywianiu i rozwijaniu poprzez kolejne reinterpretacje ${ }^{2}$, nie ograniczy się do rekonstrukcji. Jakkolwiek bowiem już sama hipoteza Podgóreckiego może być postrzegana jako wyraz integracyjnego (przede wszystkim w znaczeniu integracji zewnętrznej) sposobu uprawiania prawoznawstwa, to jej walory integracyjne polegają również na tym, że stwarza ona możliwość i pokusę wykonania kolejnych kroków w stronę interdyscyplinarnego myślenia o prawie. Chęć taka wynika nie tylko ze szkicowego, a więc prowokującego do dopełniania, charakteru hipotezy trójstopniowego działania prawa, lecz również z interesujących korelacji - o których dalej - między ustaleniami Podgóreckiego a twierdzeniami wypracowanymi poza szeroko rozumianym prawoznawstwem.

Poniższe rozważania składają się z trzech części. W pierwszej zostanie zrekonstruowana hipoteza trójstopniowego działania prawa. W części drugiej piszący te słowa będzie się tłumaczył z pomysłu zestawiania koncepcji Adama Podgóreckiego i Ericha Fromma. Wreszcie trzecia część będzie poświęcona

1 A. Podgórecki, Socjologia prawa, Warszawa 1962, s. 8.

2 O. Marquard, Pytanie o pytanie, na które odpowiedzia jest hermeneutyka, [w:] idem, Rozstanie z filozofia pierwszych zasad. Studia filozoficzne, Warszawa 1994, s. 132-133. 
aplikowaniu wypracowanych przez autora Ucieczki od wolności pojęć charakteru społecznego i dwóch modusów egzystencji do hipotezy trójstopniowego działania prawa.

1. Hipoteza trójstopniowego działania prawa została sformułowana w pracy Prestiz prawa $^{3}$, a następnie powtórzona m.in. w Zarysie socjologii prawa ${ }^{4}$ oraz przypomniana na nieco zmodyfikowany sposób w zamykającej dorobek polskiego badacza książce Socjologiczna teoria prawa . Hipoteza ta głosi, że oddziaływanie przepisu prawnego (który to termin jest używany przez Podgóreckiego zamiennie z terminem „norma prawna”) na konkretną, rzeczywistą praktykę zależy od następujących trzech zmiennych: po pierwsze, od ustroju społeczno-gospodarczego (w wersji późniejszej - ustroju społecznego), po drugie, od podkultury, w ramach której ma miejsce aplikacja przepisu, po trzecie wreszcie, od osobowości podmiotu dokonującego owej aplikacji ${ }^{6}$. Całość wywodów Podgóreckiego, a w szczególności podawane przez niego przykłady, nie pozostawiają wątpliwości, że hipoteza ta dotyczy nie tylko oddziaływania prawa wśród ,zwykłych obywateli”, tj. osób niebędących prawnikami, lecz odnosi się również do podmiotów zajmujących się profesjonalnym stosowaniem prawa ${ }^{7}$. Jakkolwiek fakt modyfikowania hipotezy trójstopniowego działania prawa, a w jeszcze większym stopniu jej szkicowy charakter oraz nie zawsze w pełni jednoznaczny sposób wykładania myśli przez polskiego socjologa

3 A. Podgórecki, Prestiż prawa, Warszawa 1966, s. 175-187.

4 A. Podgórecki, Zarys socjologii prawa, Warszawa 1971, s. 417-440.

5 A. Podgórecki, Socjologiczna teoria prawa, Warszawa 1998, s. 24-36. Zob. też: K. Frieske, Socjologia prawa, Warszawa-Poznań 2001, s. 111-114; A. Pieniążek, M. Stefaniuk, Socjologia prawa. Zarys wyktadu, Zakamycze 2005, s. 160-163.

6 A. Podgórecki, Prestiz prawa, s. 175-176. Czytamy tam m.in.: „Hipoteza trójstopniowego działania prawa brzmi: wydany przez normodawcę abstrakcyjny przepis prawny oddziałuje na zachowanie społeczne poprzez trzy zasadnicze zmienne. Pierwszą zmienną niezależną jest treść, znaczenie, jakie danemu przepisowi prawnemu nadaje rodzaj, typ stosunków społeczno-gospodarczych, w ramach których ów przepis jest elementem obowiązującego systemu prawnego. Drugą zmienną niezależną jest rodzaj, typ podkultury, który działa w ramach danego ustroju społeczno-gospodarczego jako łącznik między poleceniami normodawcy a społecznymi zachowaniami odbiorców przepisów prawnych. Trzecią zmienną niezależną, która może rozmaicie modyfikować funkcjonowanie abstrakcyjnego przepisu prawnego jest - w ramach danego ustroju społeczno-gospodarczego i w ramach danej podkultury prawnej - typ osobowości, który jest ostatecznym realizatorem zaleceń danego przepisu".

7 Na marginesie trzeba jednak odnotować, że istnieje pewne napięcie między tak szerokim odnoszeniem tej hipotezy a jej genezą, tj. powstaniem jako teorii uogólniającej wyniki empirycznych badań nad prestiżem prawa, przeprowadzanych jednak bez wyodrębniania prawników jako osobnej badanej grupy. Na podstawie raportu z badań nie wiemy nawet, czy wśród badanej grupy był jakikolwiek prawnik. Zastrzeżenie to staje się jednak mniej istotne, jeśli przyjąć - co w świetle dorobku naukowego Podgóreckiego jest jak najbardziej uprawnione - że wspomniane badanie było tylko jednym z impulsów do sformułowania hipotezy trójstopniowego działania prawa. 
czynią poniższe przedsięwzięcie nieco ryzykownym, spróbujmy dokładniej zrekonstruować strukturę czynników, mających warunkować przekuwanie tekstów prawnych na praktykę społeczną.

Pierwszym z nich jest szeroko ujmowany ustrój społeczno-polityczno-gospodarczy. Wydaje się, że na podstawie lektury Socjologicznej teorii prawa można zaproponować dwa dopełniające się znaczenia owej zmiennej ustrojowej. $Z$ jednej strony bowiem chodzi o wymiar normatywny, przejawiający się zarówno w społecznym poczuciu prawa (Podgórecki używa w tym kontekście zaczerpniętego od Leona Petrażyckiego terminu „prawo intuicyjne”), jak i w kształcie obowiązującego porządku prawnego (tu z kolei zapożyczony jest termin „prawo oficjalne”). Gdyby zgodzić się na pewne uproszczenie, to można powiedzieć, że ową pierwszą składową zmiennej ustrojowej jest to, co współcześnie określa się mianem moralności politycznej porządku prawnego, tj. „zbiór norm moralnych zrekonstruowanych i przyjmowanych przez jakieś podmioty [...], regulujących cel, któremu ma służyć dany porządek prawny w państwie"». Jest jednak jeszcze i druga strona uwarunkowań ustrojowych, o której czytamy: „Zmienna systemowa w szerszym sensie odnosi się głównie do strukturalnych uwarunkowań systemu społecznego. Naciski ze strony różnych ciał społecznych, instytucji, organizacji, klas i rozmaitych grup społecznych w sposób oczywisty zmieniają percepcję i stosowanie prawa". O ile zatem wcześniej wskazany czynnik miał charakter normatywny, o tyle tutaj mowa jest o pewnej sferze faktyczności, pojmowanej - jak się zdaje - w duchu bliskim marksistowskiemu, czy może po prostu antagonistycznemu ujęciu społeczeństwa jako areny walki między różnymi grupami. Odróżnienie tych dwóch składowych zmiennej ustrojowej wydaje się pożyteczne m.in. z tego powodu, że stwarza przestrzeń do pomieszczenia możliwego napięcia między tym, co normatywne i tym, co faktyczne. Dobrej ilustracji takiej sytuacji dostarcza przykład, którym Podgórecki posłużył się w celu ukazania istnienia owej faktycznej warstwy uwarunkowań ustrojowych. Polski socjolog wskazuje mianowicie na przeprowadzone przez innego naukowca badania, wykazujące korelację między statusem społecznym podsądnego (wyznaczanym na podstawie zawodu i dochodów) a rodzajem decyzji podejmowanej przez sądy. Statystycznie rzecz biorąc, rozstrzygnięcia w sprawach osób znajdujących się na samej górze skali statusu społecznego były dużo bardziej korzystne dla podsądnych, niż w przypadku osób reprezentujących grupę $\mathrm{z}$ drugiego bieguna skali ${ }^{10}$. Tego typu różnica nie znajdowała uzasadnienia w normatywnej warstwie czynników ustrojowych. Innego przykładu możliwych rozbieżności między normatywnym a faktycznym

8 Definicja zaczerpnięta z: M. Smolak, Uzasadnienie sqdowe jako argumentacja z moralności politycznej. O legitymizacji władzy sędziowskiej, Zakamycze 2003, s. 32.

9 A. Podgórecki, Socjologiczna teoria..., s. 26.

${ }^{10}$ Ibidem. 
wymiarem czynników ustrojowych dostarcza formułowane współcześnie oskarżenie pod adresem zachodnich systemów prawnych, że w ukryty i przesadny sposób podporządkowane są potrzebom ekonomii ${ }^{11}$. Powyższe przykłady nie miały jednak wykazać, że normatywna warstwa czynników ustrojowych nie ma realnego oddziaływania. Twierdzenie było znacznie słabsze, chodziło bowiem tylko o to, że warstwa ta nie jest tu jedynym elementem sprawczym.

Drugim czynnikiem determinującym sposób przekładania tekstów prawnych na praktykę jest - wedle hipotezy trójstopniowego działania prawa podkultura. Podgórecki explicite stwierdza, że można mówić o niej zarówno w odniesieniu do „zwykłych obywateli”, tj. nieprawników, jak i w odniesieniu do podmiotów zajmujących się profesjonalną obsługą prawną ${ }^{12}$. W nawiązaniu do rozróżnienia terminologicznego, zaproponowanego kiedyś przez Krzysztofa Pałeckiego, przeciwstawiającego kulturę prawną i kulturę prawniczą ${ }^{13}$, można więc - wprowadzając małą korektę - odpowiednio mówić o podkulturze prawnej i podkulturze prawniczej.

Podobnie jak to miało miejsce w przypadku uwarunkowań ustrojowych, również w odniesieniu do podkultury daje się zauważyć wysoce niejednorodny charakter konstytuujących ją czynników. W grę wchodzą mianowicie takie elementy, jak: przekonania dominujące w określonych grupach społecznych; różnego rodzaju regulacje normatywne poszczególnych zawodów prawniczych i nieprawniczych; style procedowania i rozstrzygania wyróżnione nie tylko ze względu na kryterium podziału geograficznego, lecz także zrelatywizowane do typów instytucji, czy też odniesione do konkretnych placówek lub nawet oddziałów wyodrębnionych $\mathrm{w}$ ramach takich placówek ${ }^{14}$. Podkulturę prawną i prawniczą można więc wyodrębnić na różnym poziomie ogólności, przy czym wydaje się, że im mniejsza skala danej podkultury, tym większy wpływ na jej kształt mogą mieć pojedyncze osoby.

Jako ilustrację istnienia podkultur prawniczych wyodrębnionych geograficznie Podgórecki wskazuje przeprowadzone w Norwegii badania orzecznictwa sądów w sprawach o uchylanie się od służby wojskowej. Analiza ta wykazała, że sądy w północnej i południowej Norwegii miały tendencję do wydawania znacznie mniej korzystnych dla podsądnych wyroków, niż sądy ze środka kraju, mimo orzekania na tej samej podstawie normatywnej. Podgórecki podsumowuje:

${ }^{11}$ Z. Bauman, Praca, konsumpcjonizm i nowi ubodzy, Kraków 2006, s. 149; idem, Ponowoczesność jako źródło cierpień, Warszawa 2000, s. 90-99, 376; N. Christie, Crime Control as Industry. Towards Gulags, Western Style, Routledge 2007, passim; Regionalizacja rozumu? Spotkanie prawa i filozofii, rozmowa Artura Kozaka z Leszkiem Kleszczem, [w:] P. Jabłoński, P. Kaczmarek, M. Paździora, M. Pichlak (red.), Perspektywy juryscentryzmu, Wrocław 2011, s. 29-31.

${ }^{12}$ A. Podgórecki, Prestiz prawa, s. 181.

${ }^{13}$ K. Pałecki, O użyteczności pojęcia ,kultura prawna”, „Państwo i Prawo” 1974, z. 2.

${ }^{14}$ A. Podgórecki, Socjologiczna teoria..., s. 26-29. 
Owej różnicy nie sposób wyjaśnić inaczej, jak przez wyraźnie różne style praktyki środowisk sędziowskich w różnych regionach. Badanie Auberta pokazuje, że w instytucjach (w tym przypadku - w sądach) może dojść do powstania specyficznej praktyki, innymi słowy - pewnego społecznie przekazywanego sposobu załatwiania spraw, lokalnego stereotypu podejmowania decyzji, odmiennego od wzorów obowiązujących gdzie indziej ${ }^{15}$.

Innymi wskazywanymi przez Podgóreckiego przykładami podkultur, tym razem prawnych, a nie prawniczych i wyodrębnionych ze względów innych niż geograficzne, są środowiska lekarzy, więźniów czy prostytutek ${ }^{16}$.

Trzecim wreszcie elementem struktury trójstopniowego działania prawa jest osobowość podmiotu stosującego dane przepisy, przy czym stosowanie należy tu rozumieć, podobnie jak to miało miejsce wcześniej, nie tylko jako aplikowanie przez profesjonalnego prawnika, lecz także jako zachowanie się ,zwykłego" adresata prawa. Warto podkreślić, że wprowadzenie do empirycznych badań nad prestiżem prawa zmiennych osobowościowych, czyli tego, co nazwano czynnikami „społeczno-subiektywnymi” oraz wykazanie ich dużego znaczenia dla przyjmowanej postawy wobec prawa zostało uznane przez Podgóreckiego za kluczowy moment owych badań ${ }^{17}$. Jakkolwiek bowiem wstępna hipoteza badawcza, wedle której posłuch dla prawa jest wprost proporcjonalny do autorytarnych predyspozycji osobowości, została częściowo sfalsyfikowana, to samo istnienie korelacji między przyjmowaną wobec prawa postawą a typem osobowości znalazło swoje potwierdzenie w wynikach. Jak czytamy w raporcie $\mathrm{z}$ tych badań, za który można uznać książkę Prestiż prawa - okazało się, że znaczenie czynników ,społeczno-subiektywnych, takich jak: poczucie zagrożenia, przystosowanie społeczne, nastawienie racjonalne względnie dogmatyczne, typ wychowania, religijność itd." 18 nie tylko nie jest mniejsze, niż rola czynników „społeczno-obiektywnych” (wiek, płeć, wykształcenie, zawód, pochodzenie społeczne, miejsce zamieszkania), ale nierzadko to właśnie owe „miękkie” determinanty osobowościowe są istotniejsze ${ }^{19}$.

Podgórecki podkreśla dwie cechy czynników osobowościowych. Pierwsza $\mathrm{z}$ nich polega na tym, że są one ukryte, stąd polski socjolog określa je mianem „,czynników niewidocznych”. Drugą cechą, związaną z poprzednią, jest z kolei to, iż znaczenie osobowościowego elementu jest w porównaniu z ustrojem i podkulturą rzadko problematyzowane przez prawoznawstwo.

${ }^{15}$ Ibidem, s. 27. Inny przykład, tym razem dotyczący istnienia geograficznie wyodrębnianych podkultur prokuratorskich znajdujemy w: A. Podgórecki, Zarys socjologii..., s. 428.

${ }^{16}$ Zob. np. A. Podgórecki, Socjologiczna teoria..., s. 28; idem, Zarys socjologii..., s. 281-303.

${ }^{17}$ A. Podgórecki, J. Kurczewski, J. Kwaśniewski, M. Łoś, Poglady społeczeństwa polskiego na moralność i prawo. Wybrane problemy, Warszawa 1971, s. 245-247.

${ }^{18}$ A. Podgórecki, Prestiz prawa, Warszawa 1966, s. 32.

${ }^{19}$ Ibidem, s. 33, 153-154. Zob. też: A. Turska, O podmiotowości prawnej i gotowości dochodzenia należnych praw, [w:] eadem (red.), Prawo i wykluczenie. Studium empiryczne, Warszawa 2010, s. 113-115. 
2. Zamiar odnoszenia dorobku wypracowanego przez Adama Podgóreckiego do elementów psychoanalitycznej myśli społecznej Ericha Fromma może budzić sprzeciw, choćby z tego powodu, że polski socjolog wielokrotnie i bardzo dobitnie manifestował swoją niechęć do wikłania badań naukowych w dyskurs filozoficzny $^{20}$. Powstaje zatem pytanie, czy łączenie socjologicznoprawnych ustaleń autora Prestiżu prawa z jakąkolwiek koncepcją filozoficzną nie jest z góry skazane na niepowodzenie w postaci swoistego teoretycznego konfliktu serologicznego. Odpowiadając negatywnie, ograniczę się do syntetycznego wyłożenia dwóch głównych, dopełniających się argumentów.

Pierwszy z nich odwołuje się do metateoretycznych badań, prowadzonych przed laty przez Jerzego Wróblewskiego ${ }^{21}$. Otóż, autor ten w przekonujący sposób wykazał, że analizując związki między koncepcjami z zakresu szeroko ujmowanej teorii prawa (w którym to obszarze bez wątpienia mieści się hipoteza trójstopniowego działania prawa) a refleksją ogólnofilozoficzną, nie należy ograniczać się do wyciągania konsekwencji z deklaracji składanych explicite przez autora badanej konstrukcji teoretycznoprawnej (badanie relacji powołania), lecz trzeba przyglądać się faktycznie zachodzącym związkom merytorycznym (badanie relacji przyporządkowania). Co więcej, Wróblewski bardzo mocno akcentował możliwość i częstość występowania sprzeczności między relacją powołania i przyporządkowania. Jego analizy uczą nas zatem tego, byśmy nie dawali zbyt łatwo wiary autorom co do deklarowanej przez nich postawy filozoficznej - czy to przyjmującej postać zapewniania o opieraniu się na jakimś konkretnym projekcie filozoficznym, czy to w postaci odwrotnej, tj. odcinania się od związków z filozofią ogólną - lecz przyglądali się możliwościom zrekonstruowania przyporządkowania. O naturze tego ostatniego pisał Wróblewski:

Wprowadzone pojęcie przyporządkowania zakłada szerokie rozumienie reguł rozumowania. Chodzi tutaj bowiem zarówno o reguły wnioskowania dedukcyjnego, jak i powiązania typu argumentacyjnego lub interpretacyjnego, o ile tego ostatniego nie traktować jako szczególnego rodzaju argumentacji [...]. Również wówczas, gdy teoria prawa może być traktowana jako interpretacja określonej filozofii chodzi o związek luźny ${ }^{22}$.

${ }^{20}$ Dla przykładu: A. Podgórecki, Socjologia ..., s. 206-207; idem, Patologia życia społecznego, Warszawa 1969, s. 54; idem, Zarys socjologii..., s. 7-28. Zob. też głosy sprzeciwiające się stanowisku Podgóreckiego w tej kwestii: K. Pałecki, G. Skąpska, Recenzja książki A. Podgóreckiego „Zarys socjologii prawa”, „Państwo i Prawo” 1972, z. 6, s. 112; K. Pałecki, O przedmiocie socjologii prawa raz jeszcze, [w:] G. Skąpska (red.), Prawo w zmieniajacym się spoleczeństwie. Księga jubileuszowa Marii Boruckiej-Arctowej, Kraków 1992, s. 34.

${ }^{21}$ J. Wróblewski, Postawa filozoficzna i afilozoficzna we współczesnej teorii prawa, „Studia Prawnicze" 1966, z. 13; idem, Filozoficzne problemy teorii prawa. Rozważania metodologiczne, „Państwo i Prawo” 1974, z. 11. Metateoretyczną koncepcję Wróblewskiego oraz związane z nią kontrowersje analizuję w: Postawa filozoficzna i afilozoficzna w namyśle nad teoriq prawa. Rzecz o aktualności metateoretycznych ustaleń Jerzego Wróblewskiego, [w:] P. Jabłoński (red.), Czy koniec teorii prawa? Z zagadnień teorii i filozofii prawa, „Acta Universitatis Wratislaviensis” nr 3337, seria: „Prawo” nr CCCXII, Wrocław 2011.

${ }^{22}$ K. Opałek, J. Wróblewski, Prawo. Metodologia, filozofia, teoria prawa, Warszawa 1991, s. 69. 
Podkreślmy zatem, że relacja przyporządkowania nie powinna być sprowadzana do zwykłej konsekwencji logicznej i może mieć ona charakter interpretacyjny. Inne, obok nieformalnego charakteru i niezależności względem relacji powołania, istotne cechy relacji przyporządkowania to: stopniowalność (nie poruszamy się więc na gruncie zero-jedynkowym), wszechobecność (każdy projekt teoretycznoprawny pozwala się przyporządkować do jakiejś koncepcji filozoficznej), wielopoziomowość (możliwość przyporządkowań zarówno na poziomie pojedynczych twierdzeń, jak i na poziomie całych koncepcji) i wreszcie możliwość istnienia przyporządkowań alternatywnych.

Mając powyższe na uwadze, możemy wprowadzić drugi argument, który przyjmuje postać wykazania kilku istotnych korelacji między koncepcją Adama Podgóreckiego a perspektywą wypracowaną przez Ericha Fromma. Odnotujmy zatem najważniejsze podobieństwa. Po pierwsze, kluczowe dla przeprowadzonych przez polskiego socjologa badań nad prestiżem prawa pojęcie „charakteru autorytarnego" zostało zapożyczone z dorobku szkoły frankfurckiej. Jeśli więc hipoteza trójstopniowego działania prawa sformułowana jest jako teoria porządkująca wyniki owych badań i jeśli poza jakimkolwiek sporem pozostaje fundamentalne znaczenie prac Fromma dla wypracowanej przez frankfurtczyków ${ }^{23}$, a następnie pozyskanej we wspomnianych badaniach przez Podgóreckiego kategorii „,charakteru autorytarnego" ${ }^{24}$, to mamy dobry powód do tego, by przyjrzeć się merytorycznym związkom między ustaleniami obu badaczy. Po drugie, warto odnotować, że w perspektywie rysowanej przez Podgóreckiego pojawiają się również inne elementy, uwikłane w psychoanalityczne i Marksowskie zaplecze teoretyczne, wykorzystywane przez szkołę frankfurcką, takie jak: superego ${ }^{25}$, związek prawa $\mathrm{Z}$ walką klas ${ }^{26}$, akcentowanie strachu jednostek przed społecznym wyobcowaniem ${ }^{27}$ czy urzeczowienie człowieka ${ }^{28}$. Po trzecie wreszcie, obydwaj badacze przyjmowali dosyć podobny paradygmat uprawiania refleksji, cechujący się niechęcią do nadmiernej spekulacji, akcentowaniem kluczowego znaczenia badań empirycznych, ścisłym łączeniem perspektywy socjologicznej z psychologiczną.

Na koniec tej części podkreślmy, że powyższe wynotowanie punktów wspólnych między teorią Podgóreckiego i dorobkiem Fromma nie ma na celu sprawić wrażenia, jakoby koncepcje te tworzyły pod każdym względem jedną przestrzeń teoretyczna. Intencja jest tu znacznie skromniejsza, idzie bowiem tylko o to, by pokazać, że częściowa integracja tych dorobków nie jest zabiegiem całkiem arbitralnym.

${ }^{23}$ Zob. M. Chałubiński, Fromm, Warszawa 2005, s. 10.

${ }^{24} \mathrm{~W}$ jednym z przypisów w Socjologii prawa (s. 67). znajdujemy bardzo syntetyczne wyjaśnienie terminu ,,autorytarny”, uzupełnione o odesłanie do pracy współautorstwa innego frankfurtczyka - Theodora W. Adorno. Ogólnie jednak polski socjolog unikał tematyzacji tego pojęcia.

${ }^{25}$ A. Podgórecki, Zarys socjologii..., s. 394.

${ }^{26}$ A. Podgórecki, Prestiz prawa, s. 171.

${ }^{27}$ A. Podgórecki, Zarys socjologii..., s. 389.

${ }^{28}$ Ibidem, s. 299. 
3. W dalszej części interesować nas będą dwa elementy systemu Fromma ${ }^{29}$, tj. pojęcie charakteru społecznego oraz twierdzenie o dwóch modusach egzystencji. Będę próbował wykazać ich kompatybilność i przydatność dla perspektywy zaproponowanej przez autora Prestiżu prawa. Trzeba przy tym podkreślić, że obydwa wskazane powyżej elementy zostały wypracowane przez Fromma jako wynik rozszerzenia i pogłębienia badań nad kategorią charakteru autorytarnego, wykorzystywaną przez Podgóreckiego.

Przez charakter społeczny Fromm rozumiał typ charakteru dominujący w danej zbiorowości, ujmowany jednak nie jako pewna prawidłowość statystyczna, lecz jako aktywna siła, wpływająca na działania poszczególnych jednostek. W Ucieczce od wolności czytamy o charakterze społecznym, że jest to „zasadnicze jądro struktury charakteru większości członków grupy, które rozwinęło się jako rezultat podstawowych doświadczeń i sposobu życia wspólnego tej grupie"30. Wedle ujęcia frankfurtczyka można mówić o następujących właściwościach charakteru społecznego.

Po pierwsze, da się go wyodrębnić na różnych poziomach analizy społecznej. A zatem można rekonstruować charakter społeczny np. takich grup, jak: naród, jakaś grupa narodów (np. tzw. społeczeństwa postkomunistyczne), wybrana klasa czy warstwa określonego społeczeństwa. Co ciekawe, współczesny psychoanalityk i komentator twórczości Fromma, Alan Grey, zwraca uwagę na zasadność odnoszenia kategorii charakteru społecznego do poszczególnych grup zawodowych. Ogólnie można więc powiedzieć, że wszędzie tam, gdzie wokół wspólnego doświadczenia konstytuuje się jakaś zbiorowość, wytrąca się to, co Fromm nazwał charakterem społecznym.

Po wtóre, kształt konkretnego charakteru społecznego jest wynikiem gry trzech rodzajów czynników: ideologicznych, ekonomicznych i psychologicznych. Pierwsze są rozumiane jako sposoby myślenia - przede wszystkim te, które przyjmują postać uporządkowaną i scaloną w różnego rodzaju doktryny, światopoglądy, całościowe wyobrażenia, koncepcje. Czynniki ekonomiczne to szeroko ujmowana baza materialna, w ramach której dana wspólnota funkcjonuje. Wydaje się więc, że o ile w przypadku całych narodów owe czynniki ekonomiczne

${ }^{29}$ Rekonstrukcję najważniejszych elementów filozofii Fromma przeprowadziłem w: Szkic portretu przywódcy w oparciu o teorię Ericha Fromma, [w:] I. Błocian, R. Saciuk (red.), Gabinet luster. Psychoanalityczne krytyki poznania, Torun 2004. Inne próby aplikowania dorobku Fromma do problematyki prawa podejmowałem w: Ericha Fromma nauka o potrzebie odpowiedzi, [w:] I. Błocian, R. Saciuk (red.), Poznać człowieka. Szkice z antropologii psychoanalizy, Toruń 2005; Populizm penalny w świetle myśli Ericha Fromma i Zygmunta Baumana, [w:] J. Skorupka, I. Hayduk-Hawrylak (red.), Współczesne tendencje w rozwoju procesu karnego. Z perspektywy dogmatyki oraz teorii i filozofii prawa, Warszawa 2011.

${ }^{30}$ E. Fromm, Ucieczka od wolności, Warszawa 1999, s. 257. Zob. też: ibidem, s. 54-108, 198-224, 257-276; E. Fromm, Anatomia ludzkiej destrukcyjności, Poznań 1999, s. 280-282; idem, Zerwać okowy iluzji. Moje spotkanie z myśla Marksa i Freuda, Poznań 2000, s. 104-183. 
przyjmują przede wszystkim postać panujących tam stosunków gospodarczych, o tyle na poziomie np. grupy zawodowej czy jakiejś konkretnej insty tucji przejawiają się w takich elementach, jak wynagrodzenie i inne warunki pracy. Czynniki psychologiczne z kolei to pewne uwarunkowania wynikające z natury ludzkiej. Ujmując rzecz najogólniej, odnotujmy, że według Fromma człowiek ma naturalną tendencję do twórczego rozwoju, której zablokowanie uruchamia z kolei mechanizmy regresywne i destrukcyjne. Owo zablokowanie może być konsekwencją indywidualnych wyborów, ale może też wynikać z kształtu kultury społeczności, w jakiej dana jednostka żyje, które to zresztą przyczyny najczęściej się dopełniają.

Trzecim ważnym elementem koncepcji charakteru społecznego jest kwestia jego zmiany. $Z$ jednej strony bowiem ma on tendencję do powolnego samorzutnego przekształcania się, co jest wynikiem dynamicznej natury wskazanych powyżej trzech czynników. $Z$ drugiej strony można próbować wpłynąć na jego kształt za pomocą szeroko zakrojonych działań socjotechnicznych. Aby jednak postępowanie takie miało jakiekolwiek widoki powodzenia, trzeba uwzględniać wszystkie trzy wyznaczniki charakteru społecznego. Dla przykładu, zaszczepienie nowych idei, czy po prostu nowych sposobów myślenia, bez uwzględnienia specyfiki aktualnej kondycji psychicznej adresatów oraz kształtu bazy materialnej jest działaniem niemającym żadnych szans na uzyskanie oczekiwanych rezultatów. I odwrotnie, zmiana samych warunków materialnych, bez równoległej pracy na poziomie idei, jest równie chybiona.

Jako czwartą cechę odnotujmy sposób działania charakteru społecznego. Jego wspomniany wyżej wpływ na wszystkie jednostki tworzące daną grupe przybiera nie tylko formy jawne, lecz również ukryte, często nieuświadamiane przez jednostkę. Wedle Fromma charakter społeczny za pośrednictwem różnorodnych bodźców, mniej lub bardziej dyskretnych, popycha poszczególne osoby do działania zgodnego z obecnym sposobem funkcjonowania danej wspólnoty. Autor Ucieczki od wolności twierdzi, że rzadkim wyjątkiem jest sytuacja, w której jednostka nie daje się ukształtować charakterowi społecznemu grupy, do której należy.

Wydaje się, iż tak ujmowane pojęcie charakteru społecznego jest bardzo dobrą kategorią eksplikacyjną dla tego, co Adam Podgórecki nazywał podkulturą, i to zarówno w jej odniesieniu do prawników, jak i nieprawników. Różne kryteria i poziomy wyodrębniania, ontologiczna niejednorodność czynników determinujących, bardzo duży (a zarazem mający tendencję do niejawności) wpływ na poczynania poszczególnych jednostek, uwikłanie w społeczną rywalizację, problematyczność przebudowywania, ugruntowanie w badaniach empirycznych - to tylko najważniejsze wspólne cechy pojęć podkultury i charakteru społecznego.

Drugi trop związany jest z twierdzeniem Fromma o dwóch modusach egzystencji. Jako punkt wyjścia można tu przyjać przyjmowaną przez frankfurtczyka charakterystykę ludzkiej sytuacji egzystencjalnej: 
Człowiek, będący wybrykiem natury - urodzony w jej obrębie, jednak poza nią wykraczający - musi znaleźć zasady działania i podejmowania decyzji, które zastąpiłyby utracone przezeń zasady instynktu. Musi posiąść ramy orientacji, umożliwiające mu stworzenie sobie spójnego obrazu świata, będącego warunkiem konsekwentnych działań. Zmuszony jest walczyć nie tylko z groźbą śmierci, głodu czy krzywdy, ale również z typową ludzką groźbą obłąkania ${ }^{31}$.

Opisywana sytuacja, nazywana przez Fromma wolnością negatywną, wymaga więc od człowieka wprowadzenia poznawczego i emocjonalnego uporządkowania, przy czym sposób uczynienia tego najczęściej jest konsekwencją rozwiązań, w które popycha charakter społeczny. Jakkolwiek możliwych rozwiązań jest tu wiele, to można je - wedle Fromma - podzielić na dwa typy: progresywne i regresywne. Pierwsze oznaczają przejście od wolności negatywnej do wolności pozytywnej, poprzez odważne i twórcze odnajdywanie się człowieka w jego egzystencjalnej sytuacji. Progresywny modus egzystencji przejawia się m.in. w zachowaniu samodzielnego myślenia, budowaniu życzliwych i niecynicznych relacji międzyludzkich, mimo świadomości ich zawodności, w twórczym i refleksyjnym podejściu do różnych sfer własnej aktywności. Odpowiedzi regresywne natomiast oznaczają ruch w drugą stronę. Polega on na prowadzącej do reifikacji próbie odzyskania pierwotnej więzi z rzeczywistością poprzez ucieczkę od wolności za pomocą jednego z badanych przez Fromma mechanizmów, takich jak konformizm, autorytaryzm, destrukcyjność czy narcyzm ${ }^{32}$. Wszystkie one są regresywną odpowiedzią na poczucie niepewności i zagrożenia związane z brakiem przejrzystości i zdeterminowania świata człowieka. Autor Ucieczki od wolności mocno podkreśla, że wybór między tymi dwoma typami egzystencji przenika najróżniejsze sfery aktywności człowieka, wpływając tym samym na całokształt jego relacji z innymi ludźmi, światem, a nawet z samym sobą.

Podział Fromma wydaje się bardzo dobrze korespondować $\mathrm{z}$ podstawową dychotomią, jaką Podgórecki wprowadził do badań nad prestiżem prawa. Polski socjolog podzielił swoich respondentów na „zwolenników filozofii ufności i życzliwości w stosunku do innych" z jednej strony oraz osobowości autorytarne z drugiej. Przy czym tę drugą grupę określał też mianem wyznawców „filozofii niepewności i zagrożenia”" ${ }^{33}$, co na gruncie koncepcji Fromma staje się znaczące, gdyż - jak przed chwilą sygnalizowaliśmy - autorytaryzm jest tam tylko jednym z mechanizmów ucieczki. Podkreślmy, że jakkolwiek pod wpływem zebranego materiału empirycznego Podgórecki modyfikował stawiane hipotezy, to nie rezygnował z wykorzystywania w nich powyższej typologii. Choć

${ }^{31}$ E. Fromm, Rewolucja nadziei, Poznań 2000, s. 88. Zob. też: idem, Ucieczka ..., s. 21-53; idem, Anatomia ..., s. 282-283; idem, Niech się stanie człowiek. Z psychologii etyki, WarszawaWrocław 2000, s. 11-99.

${ }^{32}$ E. Fromm, Ucieczka..., s. 140-197; idem, Serce człowieka. Jego niezwykła zdolność do dobra i zła, Warszawa-Wrocław 2000, s. 116-122.

${ }^{33}$ A. Podgórecki, Prestiż prawa, s. 40. 
twierdzenie, wedle którego osoby o charakterze autorytarnym mają większą skłonność do rygorystycznego przestrzegania prawa, zostało częściowo sfalsyfikowane i jako takie zastąpione inną hipotezą, ciekawszą i znacznie bardziej skomplikowaną, to również ona bazowała na wspomnianej typologii osobowości. Wedle tego nowego ujęcia różnica $\mathrm{w}$ zakresie przestrzegania prawa przez te dwa typy osobowości nie tyle polega na stopniu posłuchu, ile na odmienności sposobów owego respektowania ${ }^{34}$. Dodajmy, że właśnie to rozpoznanie wydaje się jedną z głównych inspiracji do sformułowania hipotezy trójstopniowego działania prawa. Potwierdzenie zasadności proponowanego tu przejścia znajdujemy ponownie u Jerzego Wróblewskiego, tym razem jednak już nie w pracach metatoretycznych, lecz w rozważaniach poświęconych analizie procesu stosowania prawa. Polski teoretyk dwukrotnie bowiem notuje na marginesie głównego wywodu adekwatność wypracowanej przez Fromma kategorii ucieczki od wolności do sytuacji prawników nadmiernie podkreślających formalizm prawa $^{35}$. Wydaje się, że jeśli perspektywa ta może być stosowana do poczynań jurystów, to a fortiori zasadne jest przyglądanie się przez jej pryzmat podejściu do prawa prezentowanemu przez nieprofesjonalistów.

$\mathrm{Na}$ koniec krótko odnotujmy, jakie pożytki płyną z odnoszenia hipotezy Podgóreckiego do perspektywy wypracowanej przez Fromma. Otóż wydaje się, że można mówić o trzech przynajmniej korzyściach z tej integracji.

Po pierwsze, wyraźna korespondencja między wynikami badaczy pracujących niezależnie od siebie podnosi wiarygodność ich ustaleń. Po drugie, wpisując hipotezę trójstopniowego działania prawa w perspektywę filozofii społecznej Fromma, umieszczamy ją w szerszej siatce pojęciowej, co nie tylko może być źródłem nowych hipotez badawczych, ale sprzyja też większej precyzji. Zauważmy, iż na potrzebę ulokowania swoich badań w jakiejś ogólniejszej perspektywie wskazywał sam Podgórecki, pisząc pod koniec rozdziału traktującego o postawach wobec prawa, że „dalsze badania i dalsze próby uogólnienia wydają się niezbędne" ${ }^{\prime 6}$. Po trzecie wreszcie, wydaje się, iż z pewną korzyścią wychodzi też z tego swoistego eksperymentu myślowego koncepcja Fromma, gdyż jej ustalenia znajdują egzemplifikację i zarazem nowe interesujące pole badawcze - prawo.

${ }^{34}$ Ibidem, s. 166.

${ }^{35}$ J. Wróblewski, Sadowe stosowanie prawa, Warszawa 1988, s. 395; idem, Wartości a decyzja sqdowa, Wrocław-Warszawa-Kraków-Gdańsk 1973, s. 90-91.

${ }^{36}$ A. Podgórecki, Zarys socjologii..., s. 396-397. 